\title{
Higenamine enhances the antitumor effects of cucurbitacin $B$ in breast cancer by inhibiting the interaction of AKT and CDK2
}

\author{
ZI-QI JIN ${ }^{1 *}$, JIAN HAO $^{2 *}$, XUE YANG ${ }^{3 *}$, JING-HUA HE $^{1}$, JING LIANG $^{1}$, JIN-WEI YUAN $^{1}$,

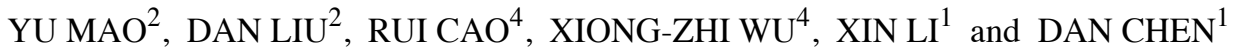 \\ ${ }^{1}$ Department of Pharmacology, School of Basic Medical Sciences, Tianjin Medical University, Tianjin 300070; \\ ${ }^{2}$ Key Laboratory of Cancer Prevention and Therapy, Tianjin Medical University Cancer Institute and Hospital, \\ National Clinical Research Center for Cancer, Tianjin 300060; ${ }^{3}$ Department of Medical Oncology, \\ Tianjin Medical University General Hospital, Tianjin 300052; ${ }^{4}$ Zhong-Shan-Men Inpatient Department, \\ Tianjin Medical University Cancer Institute and Hospital, Tianjin 300060, P.R. China
}

Received October 29, 2017; Accepted June 7, 2018

DOI: 10.3892/or.2018.6629

\begin{abstract}
Cucurbitacin B $(\mathrm{Cu} \mathrm{B})$, a tetracyclic triterpenoid derived from Trichosanthes kirilowii Maxim, exhibits anticancer effects against various types of tumor. Higenamine, isolated from Radix Aconiti Lateralis Preparata, has been used as a dietary supplement for regulating metabolic function. The present study suggested that higenamine enhances $\mathrm{Cu}$ B-induced cytotoxicity in breast cancer cells and in vivo. Network pharmacology analysis was used to identify the possible mechanism of action. $\mathrm{Cu} \mathrm{B}$ alone inhibited breast cancer cell growth, induced apoptosis, and arrested the cell cycle in the $\mathrm{G} 2 / \mathrm{M}$ phase. $\mathrm{Cu} \mathrm{B}$ combined with higenamine potentiated the cytotoxic effect of $\mathrm{Cu} B$, resulting in the enhanced induction of apoptosis and G2/M arrest. The network pharmacology analysis also found that the major predicted targets of $\mathrm{Cu} \mathrm{B}$ in breast cancer were $\mathrm{AKT}$, endoplasmic reticulum, farnesyltransferase, CAAX box, $\alpha$, platelet-derived growth factor receptor $\alpha$, peroxisome proliferator-activated receptor, RET proto-oncogene, and vascular endothelial growth factor $\mathrm{A}$. The possible targets of higenamine involved in the synergic action were cyclin A2, cyclin-dependent kinase 2 (CDK2), dihydrofolate reductase, and protein kinase CAMP-activated catalytic subunit $\alpha$. The associated pathways were summarized by Kyoto Encyclopedia of Genes
\end{abstract}

Correspondence to: Professor Dan Chen, Department of Pharmacology, School of Basic Medical Sciences, Tianjin Medical University, 22 Qixiangtai Road, Tianjin 300070, P.R. China E-mail: ilvcd@163.com

*Contributed equally

Abbreviations: $\mathrm{Cu} \mathrm{B}$, cucurbitacin $\mathrm{B}$; TCM, traditional Chinese medicine

Key words: breast cancer, cucurbitacin B, higenamine, network pharmacology, AKT, cyclin-dependent kinase 2 and Genomes pathway analysis, and it was hypothesized that higenamine may enhance the antitumor effects of $\mathrm{Cu} \mathrm{B}$ in breast cancer through inhibition of the interaction of AKT and CDK2. The protein expression was assayed by western blot analysis. The combined treatment also resulted in significant inhibition of growth in vivo.

\section{Introduction}

Breast cancer is the second most common cause of cancer-associated mortality in women following lung cancer; it is estimated that, 266,120 women will be diagnosed with breast cancer and 40,920 women will succumb to mortality from breast cancer in the United States in 2018 (1).

In order to reduce the side effects and enhance the efficacy of treatment, traditional Chinese medicine (TCM) prescriptions of synergistic combinations of different herbs have emerged as an alternative strategy for cancer therapy. The combination of cucurbitacin $\mathrm{B}(\mathrm{Cu} \mathrm{B})$ with another appropriate drug, for example curcumin, can decrease the dosage of $\mathrm{Cu} \mathrm{B}$, resulting in reduced toxicity and fewer side effects (2). Our previous study found that $\mathrm{Cu}$ B synergistically eliminated the resistance of Burkitt's lymphoma Ramos cells to apoptosis via arsenic trioxide through inhibiting the phosphorylation of signal transducer and activator of transcription 3 (3).

Trichosanthes kirilowii Maxim and Radix Aconiti Lateralis Preparata are included in the 18 incompatible medications that have been long established in TCM. The use of these two herbs together has also been recorded in ancient formulas, including Qian Jin Yi Fang (4) compiled by Simiao Sun in the Tang Dynasty, Sheng Ji Zong Lu (5) from the Song Dynasty, and Jin Gui Yao Lue (6), compiled by Zhongjing Zhang in the Eastern Han Dynasty. Cu B, a tetracyclic triterpene compound extracted from T. kirilowii Maxim, is reported to have antiproliferative activity in various types of cancer cell, including lung (7), liver (8), colorectal (9), pancreatic cancer (10) and lymphoma (3). In the toxic herb Radix Aconiti Lateralis Preparata, several components are toxic, including aconitine, which is the major toxic substance. However, higenamine can be used as a food supplement (11), as a potential 
$\beta 2$-adrenergic receptor agonist (12), and as a dietary supplement without adverse drug reactions (13), which confirms its toxicity is lower than that of aconitine. Therefore, higenamine was selected in the present study and $\mathrm{Cu} \mathrm{B}$, extracted from T. kirilowii Maxim, was combined with higenamine, the active ingredient of Radix Aconiti Lateralis Preparata, for the treatment of breast cancer. The aim of the present study was to clarify whether higenamine enhances the anticancer effects of $\mathrm{Cu} \mathrm{B}$ in breast cancer cell lines.

The combinations within TCM form a complex system with multiple components and targets; however, network pharmacology can bridge the gap between TCM and modern medicine, link drugs and targets, and can be analyzed to reveal the possible mechanisms (14). Therefore, in the present study, to provide an explanation for the possible mechanisms, network pharmacology methods were used.

The present study aimed to clarify whether incompatible drugs can be combined together at a specific ratio to exert synergistic effects. In TCM, there are 18 incompatible herbs which include T. kirilowii Maxim and Radix Aconiti Lateralis Preparata. The incompatible herbs indicate that when both herbs are used together, severe toxicity or side effects occur. The present study suggested the 18 incompatible herbs are not strictly forbidden.

\section{Materials and methods}

Cell culture and compounds. The SKBr3 and T47D cell lines were purchased from the Chinese Academy of Medicine Science (Beijing, China) and cultured in RPMI-1640, supplemented with $10 \%$ fetal bovine serum (FBS; Hyclone Laboratories; GE Healthcare Life Sciences, Logan, UT, USA) at $37^{\circ} \mathrm{C}$ in a humidified atmosphere with $5 \% \mathrm{CO}_{2} . \mathrm{Cu} \mathrm{B}$ was purchased from Tianjin Pharmacopoeia Standard Instrument Pharmaceutical Development Company (Tainjin, China) and dissolved in dimethylsulfoxide (DMSO) to produce a stock solution of $70 \mu \mathrm{mol} / \mathrm{ml}$. Higenamine was purchased from Shanghai Yuanye Biological Technology Co., Ltd. (Shanghai, China), and dissolved in DMSO at $10 \mu \mathrm{mol} / \mathrm{ml}$. MK-2206 was purchased from Selleck Chemicals (Houston, TX, USA).

Cell proliferation assay. The cells $\left(5 \times 10^{4}\right.$ cells $\left./ \mathrm{ml}\right)$ were seeded in 96-well plates, with three wells seeded per treatment group, and were treated with $\mathrm{Cu} \mathrm{B}$ at different concentrations at $37^{\circ} \mathrm{C}$. The T47D cells were exposed to serial concentrations of 5, 10 or $20 \mu \mathrm{M}$ of $\mathrm{Cu} \mathrm{B}$ and/or $0.5,1$ or $2 \mu \mathrm{M}$ of higenamine for 24 , 48 or $72 \mathrm{~h}$. The SKBr3 cells were exposed to 15,30 or $60 \mathrm{nM}$ of $\mathrm{Cu} \mathrm{B}$ and/or 1.5, 3 or $6 \mathrm{nM}$ of higenamine for 24,48 or 72 h. Cell Counting Kit-8 (CCK-8) (10 $\mu$ l; Dojindo Molecular Technologies, Inc., Kumamoto, Japan) was added to each well containing $100 \mu \mathrm{l}$ culture medium and the absorbance at $450 \mathrm{~nm}$ of each well was measured using an ultramicroplate reader. The results shown are the mean values of three independent experiments.

Apoptosis analysis. The Annexin V-FITC Apoptosis Detection kit (BD Pharmingen; BD Biosciences, San Jose, CA, USA) was used to measure apoptosis. For the assay, the SKBr3 or T47D cells $\left(2 \times 10^{4} / \mathrm{ml}\right)$ in $2 \mathrm{ml}$ were seeded in 6 -well plates and treated with the indicated concentrations of $\mathrm{Cu} \mathrm{B}$ and/or higenamine for $24 \mathrm{~h}$. The SKBr3 cells were treated with $30 \mathrm{nM}$ $\mathrm{Cu} \mathrm{B}$ and/or $3 \mathrm{nM}$ higenamine for $24 \mathrm{~h}$. The T47D cells were treated with $5 \mu \mathrm{M} \mathrm{Cu} \mathrm{B}$ and/or $500 \mathrm{nM}$ higenamine for $24 \mathrm{~h}$.

Nuclear staining with 4,6-diamidino-2-phenylindole (DAPI). For staining, $2 \times 10^{4}$ cells (SKBr3 and T47D) were plated on sterilized coverslips in 12-well plates and treated with $\mathrm{Cu} \mathrm{B}$ and/or higenamine. The SKBr3 cells were treated with $30 \mathrm{nM} \mathrm{Cu} B$ and/or $3 \mathrm{nM}$ higenamine for $24 \mathrm{~h}$. The T47D cells were treated with $5 \mu \mathrm{M} \mathrm{Cu} \mathrm{B}$ and/or $500 \mathrm{nM}$ higenamine for $24 \mathrm{~h}$. Following incubation, the cells were fixed in $4 \%$ paraformaldehyde for $20 \mathrm{~min}$ at room temperature and permeabilized with $0.2 \%$ Triton $\mathrm{X}-100$ for $5 \mathrm{~min}$. Finally, the cells were stained with DAPI solution and examined using a fluorescence microscope (Leica TCS SP5; Leica Microsystems, Inc., Buffalo Grove, IL, USA).

Cell cycle analysis. The T47D and SKBr3 cells $\left(2 \times 10^{4} / \mathrm{ml}\right)$ were seeded in 6-well plates and treated with $\mathrm{Cu} \mathrm{B}$ and higenamine. The SKBr3 cells were treated with $30 \mathrm{nM} \mathrm{Cu} \mathrm{B}$ and/or $3 \mathrm{nM}$ higenamine for $24 \mathrm{~h}$. The T47D cells were treated with $5 \mu \mathrm{M} \mathrm{Cu} \mathrm{B}$ and/or $500 \mathrm{nM}$ higenamine for $24 \mathrm{~h}$. The cells were then trypsinized, washed with ice-cold phosphate-buffered saline (PBS), fixed in $70 \%$ ethanol overnight at $-20^{\circ} \mathrm{C}$, and then stained with PI $(50 \mu \mathrm{g} / \mathrm{ml})$ and RNase $(100 \mu \mathrm{g} / \mathrm{ml})$ for $30 \mathrm{~min}$ at $37^{\circ} \mathrm{C}$. The DNA distribution was analyzed by flow cytometry using ModFit 3.1 software (Verity Software House, Groton, MA, USA).

Predicted mechanism of action of the combination of $C u B$ and higenamine in breast cancer treatment. The predicted targets of $\mathrm{Cu} \mathrm{B}$ and higenamine were obtained from ChemMapper (http://lilab.ecust.edu.cn/chemmapper/) (15), which predicts the polypharmacological effects and modes of action for small molecules based on 3D similarity. The simplified molecular-input line-entry system (SMILES) notations for $\mathrm{Cu} \mathrm{B}$ and higenamine were obtained from PubChem (https://pubchem.ncbi.nlm.nih.gov/) (16). For $\mathrm{Cu} \mathrm{B}$, the SMILES notation was $\mathrm{CC}(=\mathrm{O}) \mathrm{OC}(\mathrm{C})(\mathrm{C}) / \mathrm{C}=\mathrm{C} / \mathrm{C}(=\mathrm{O})$ $[\mathrm{C} @ @](\mathrm{C})([\mathrm{C} @ \mathrm{H}] 1[\mathrm{C} @ @ \mathrm{H}](\mathrm{C}[\mathrm{C} @ @] 2([\mathrm{C} @ @] 1(\mathrm{CC}=\mathrm{O})$ $[\mathrm{C} @ @] 3([\mathrm{C} @ \mathrm{H}] 2 \mathrm{CC}=\mathrm{C} 4[\mathrm{C} @ \mathrm{H}] 3 \mathrm{C}[\mathrm{C} @ @ \mathrm{H}](\mathrm{C}(=\mathrm{O}) \mathrm{C} 4(\mathrm{C}) \mathrm{C})$ $\mathrm{O}) \mathrm{C}) \mathrm{C}) \mathrm{C}) \mathrm{O}) \mathrm{O}$ and for higenamine, the SMILES notation was $\mathrm{C} 1 \mathrm{CNC}(\mathrm{C} 2=\mathrm{CC}(=\mathrm{C}(\mathrm{C}=\mathrm{C} 21) \mathrm{O}) \mathrm{O}) \mathrm{CC} 3=\mathrm{CC}=\mathrm{C}(\mathrm{C}=\mathrm{C} 3) \mathrm{O}$. As $\mathrm{Cu} \mathrm{B}$ has clear, direct anti-breast cancer effects, the targets of $\mathrm{Cu} \mathrm{B}$ were compared with breast cancer treatment targets, which were elucidated in our previous study (17). The interactions of the matched targets and the targets of higenamine were obtained from the Search Tool for the Retrieval of Interacting Genes (STRING) database (version 10.5) (https://string-db. org/) (18) and remapped using Cytoscape software (19) (version 3.4.0). Pathway enrichment analysis was performed online using the Comparative Toxicogenomics Database (http://ctdbase.org/tools/analyzer.go) (20) and FunRich software (version 3.1.3) (21) using the targets of higenamine that have direct interactions with the matched targets of $\mathrm{Cu} B$.

In vivo SKBr3 xenograft model. The present study was approved by the Committee on the Ethics of Animal Experiments of Tianjin Medical University Cancer Institute and Hospital (Tianjin, China; permit no. 2017083). A total of 29 female BALB/c nude mice (3-4 weeks old) weighing 
15-18 g were obtained from Beijing Vital River Laboratory Animal Technology Co., Ltd. (Beijing, China). The mice were housed in a specific pathogen-free grade laboratory in a 12-h light/black cycle environment at $22 \pm 2^{\circ} \mathrm{C}$ with ad libitum access to water and food. SKBr3 cells $\left(0.1 \mathrm{ml}, 0.2 \times 10^{7} / \mathrm{ml}\right)$ were subcutaneously implanted in the right flank of one mouse. When the tumor diameter reached $\sim 1.0 \mathrm{~cm}$, the mice were sacrificed and the tumors were excised. The tumors were cut into sections of approximate volume of $8 \mathrm{~mm}^{3}$ and transplanted subcutaneously into the other 28 female nude mice. The mice were then randomized into the following treatment groups: control (saline, $\mathrm{n}=7)$; $\mathrm{Cu} \mathrm{B}(\mathrm{n}=7)$; higenamine $(\mathrm{n}=7)$; and $\mathrm{Cu} \mathrm{B}+$ higenamine $(\mathrm{n}=7)$. The mice were intraperitoneally injected with vehicle, $\mathrm{Cu} \mathrm{B}(500 \mu \mathrm{g} / \mathrm{kg})$, and/or higenamine $(25 \mu \mathrm{g} / \mathrm{kg})$ every other day for 13 days. The tumor volume and body weight were monitored once every 2 days. The tumor volume was calculated as $\mathrm{L} \times \mathrm{W}^{2} / 2$, where $\mathrm{L}$ and $\mathrm{W}$ are the length and width of the tumor, respectively. After 13 days, the mice were sacrificed with pentobaribital sodium at a dose of $100 \mathrm{mg} / \mathrm{kg}$, and the tumors were excised. The major organs, including the heart, liver, spleen, lung and kidney, were excised and weighed.

Western blot analysis. The T47D or SKBr3 cells $\left(2 \times 10^{4} / \mathrm{ml}\right)$ were plated in 6 -well plates. The SKBr3 cells were treated with $30 \mathrm{nM} \mathrm{Cu} \mathrm{B}$ and/or $3 \mathrm{nM}$ higenamine for $24 \mathrm{~h}$. The T47D cells were treated with $5 \mu \mathrm{M} \mathrm{Cu} \mathrm{B}$ and/or $500 \mathrm{nM}$ higenamine for $24 \mathrm{~h}$. For network pharmacology evaluation, the SKBr3 cell line was first exposed to the AKT inhibitor, MK-2206, for $6 \mathrm{~h}$, and treated with $\mathrm{Cu} \mathrm{B}$ for $24 \mathrm{~h}$. Following treatment, the cells were collected, washed twice with ice-cold PBS, and lysed with RIPA buffer supplemented with $1 \%$ phosphatase inhibitor, $1 \%$ protease inhibitor and $1 \mathrm{mM}$ PMSF. The protein concentration was determined by BCA method. Equal amounts of samples were loaded and separated by $10 \%$ SDS-PAGE, transferred electrophoretically onto polyvinylidene difluoride membranes (EMD Millipore, Billerica, MA, USA). Membranes were blocked with Tris-buffered saline and Tween-20 (TBST) containing 5\% skim milk and blotted with antibodies against AKT produced in rabbit (1:1,000; cat. no. YT6111; ImmunoWay Biotechnology Company, Plano, TX, USA), phosphorylated (p-)AKT produced in rabbit (Ser473, 1:1,000; cat. no. 4060S; Cell Signaling Technology, Inc., Danvers, MA, USA), B-cell lymphoma 2 produced in rabbit (Bcl-2; 1:1,000; cat. no. ab32124; Abcam, Cambridge, MA, USA), Bcl-2-associated $\mathrm{X}$ protein produced in rabbit (BAX; 1:1,000, cat. no. ab32503, Abcam), cyclin A2 produced in mouse (CCNA2; 1:2,000; cat. no. 4656S; Cell Signaling Technology, Inc., Danvers, MA, USA), cyclin-dependent kinase (CDK)2 produced in rabbit (1:1,000; cat. no. ab32147; Abcam), p-CDK2 produced in rabbit (Thr39, 1:300; cat. no. ab79379; Abcam), p-histone H3 produced in rabbit (Ser 10, 1:200; cat. no. ab47297; Abcam), $\beta$-actin produced in mouse (1:2,000; cat. no. A1978; Sigma Chemical Co., St. Louis, MO, USA) overnight at $4^{\circ} \mathrm{C}$. After washing with TBST, the membranes were incubated with horseradish peroxidase-conjugated goat anti-rabbit (1:500; cat. no. SH-0031; Ding Guo Chang Sheng, Beijing, China) or anti-mouse IgG (1:500; cat. no. SH-0021; Ding Guo Chang Sheng) at $4^{\circ} \mathrm{C}$ for $1 \mathrm{~h}$. And the protein levels were detected using enhanced chemiluminescence reagent. The protein levels were detected using ImageJ $1.47 \mathrm{v}$ (National Institutes of Health, Bethesda, MD, USA).
Statistical analysis. The results of the CCK-8 experiments and in vivo experiments are presented as the mean \pm standard deviation. The statistical significance was analyzed by one-way analysis of variance computed using SPSS 21.0 software (IBM Corp., Armonk, NY, USA). Student's t-test was used to analyze the significance of the two single-agent groups. $\mathrm{P}<0.05$ was considered to indicate a statistically significant difference.

\section{Results}

Higenamine enhances the inhibitory effects of $C u B$ on breast cancer cells in vitro. The viability of T47D breast cancer cells treated individually with $\mathrm{Cu} \mathrm{B}$ or higenamine, or their combination, was analyzed following treatment for 24,48 and $72 \mathrm{~h}$ using the CCK-8 assay. As shown in Fig. 1A, the growth of T47D cells was significantly inhibited by $\mathrm{Cu} B$ in a concentration- and time-dependent manner. By contrast, higenamine only marginally affected cell viability and no dose-dependency was observed. The ratios at 1:1, 1:2 and 2:1 (Cu B:higenamine) were examined, and it was found that higenamine did not enhance the inhibitory effect of $\mathrm{Cu} \mathrm{B}$ at the ratios of $1: 1$ or $1: 2$. At the ratio of $2: 1$, higenamine enhanced the inhibitory effect of $\mathrm{Cu} B$ with no dose-independent effect (data not shown). Therefore, the proportion of $\mathrm{Cu} \mathrm{B}$ was increased in the combination with higenamine and the effects at the ratios of 5:1, 10:1, 20:1, and 30:1 were compared. Following combination treatment of $\mathrm{Cu} \mathrm{B}$ and higenamine at the ratios of 5:1, 10:1, 20:1 and 30:1, the combination of the agents significantly enhanced the antiproliferative effect compared with administration of the drugs separately. Among the ratios assessed, the 10:1 ratio resulted in the most marked inhibition of cell growth. The combined antitumor effects of $\mathrm{Cu} \mathrm{B}$ and higenamine were assessed in another breast cancer cell line, SKBr3, at the 10:1 ratio. The SKBr3 cells were exposed to 15,30 or $60 \mathrm{nM} \mathrm{Cu} \mathrm{B}$, and 1.5, 3 or $6 \mathrm{nM}$ of higenamine, respectively, for 24,48 and $72 \mathrm{~h}$. As shown in Fig. 1B, the individual administration of $\mathrm{Cu} B$ also inhibited the growth of the SKBr3 cells; furthermore, the inhibitory effect was enhanced by higenamine.

Combination of $C u B$ and higenamine in the induction of apoptosis. The induction of apoptosis by the combination treatment of $\mathrm{Cu} \mathrm{B}$ and higenamine in breast cancer cells was assessed using DAPI staining and Annexin V/PI double staining. The number of the breast cancer cells markedly decreased (Fig. 2A and B) and the cell condition gradually deteriorated following treatment with $\mathrm{Cu} \mathrm{B}$ and the combination, as determined using microscopic observation. The DAPI staining showed that the combination of $\mathrm{Cu} B$ and higenamine induced nuclear chromatin condensation and granular apoptotic bodies. The proportion of apoptotic cells was higher following the combination treatment of $\mathrm{Cu} \mathrm{B}$ and higenamine compared with the administration of either agent individually in the SKBr3 and T47D cell lines, as shown by flow cytometric evaluation of the Annexin V/PI double-stained cells (Fig. 3A and B).

Combination of $C u B$ and higenamine in the induction of $G 2 / M$ cell cycle arrest in breast cancer cells. To examine whether $\mathrm{Cu} \mathrm{B}$ and/or higenamine inhibited cell proliferation via cell cycle arrest, flow cytometric analysis was performed to investigate the 

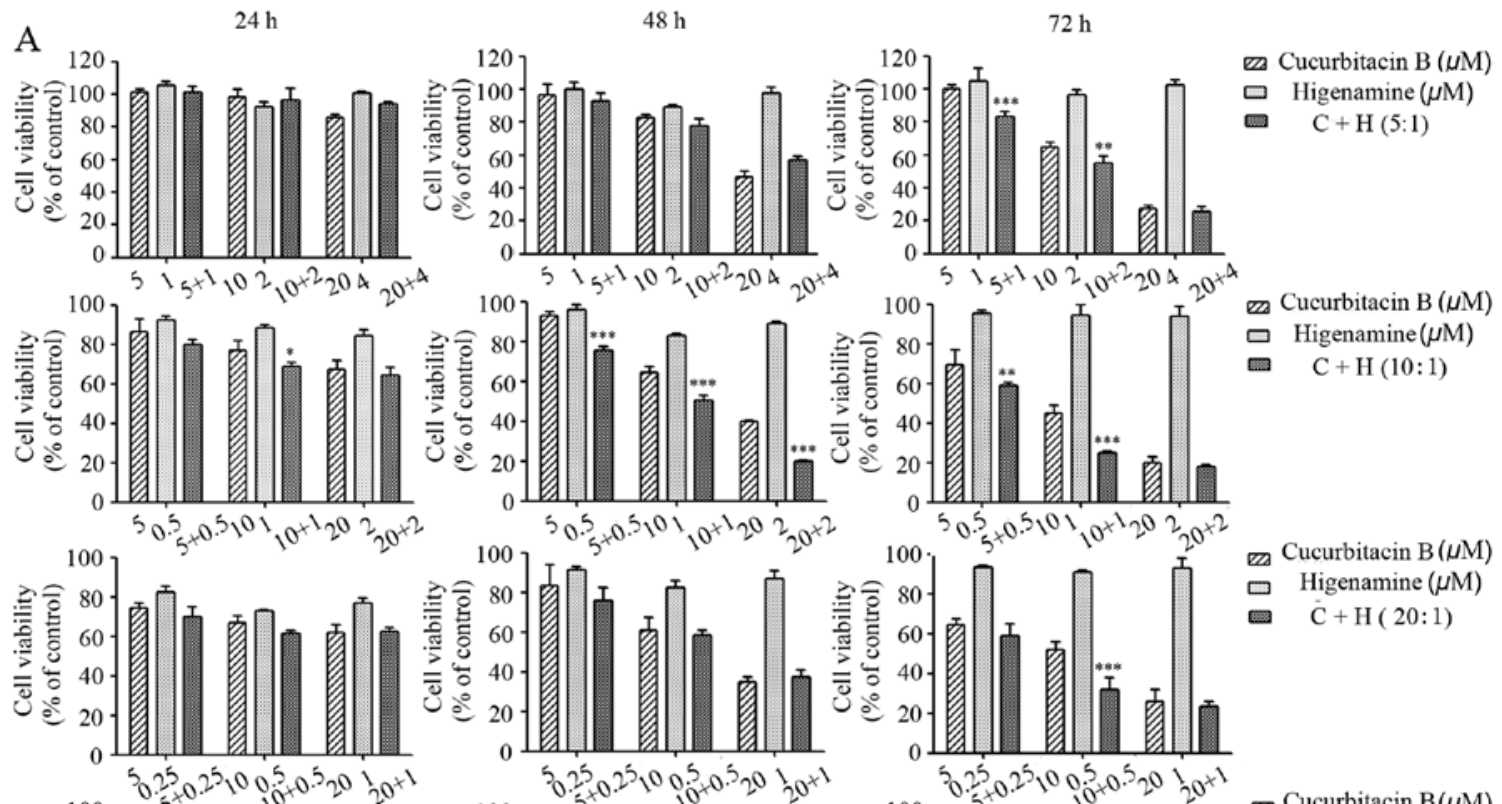

Cucurbitacin B $(\mu \mathrm{M})$

$\square$ Higenamine $(\mu \mathrm{M})$

$\square \mathrm{C}+\mathrm{H}(10: 1)$
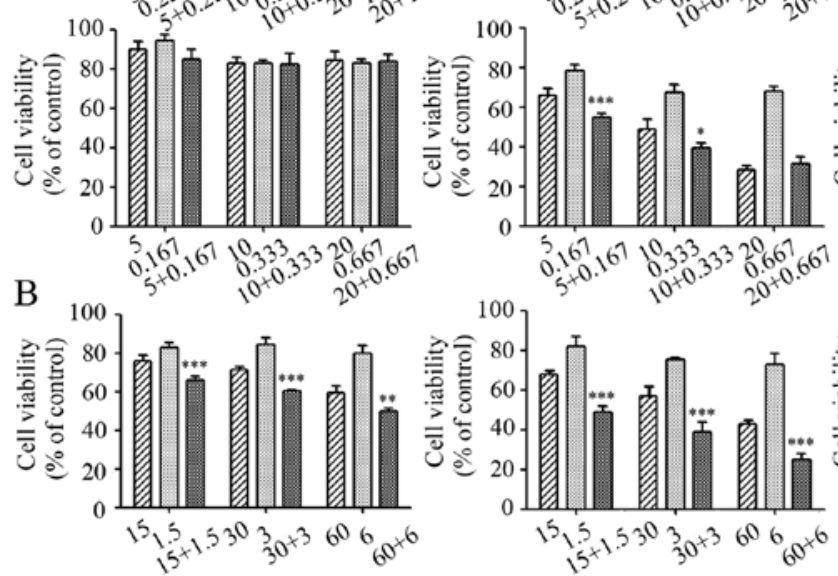

Cucurbitacin B $(\mu \mathrm{M})$
$\square \quad$ Higenamine $(\mu \mathrm{M})$
$\square \quad \mathrm{C}+\mathrm{H}(5: 1)$

- $\mathrm{C}+\mathrm{H}(20: 1)$

Figure 1. Effect of $\mathrm{Cu} \mathrm{B}$ and higenamine on the cell viability of breast cancer cell lines. (A) T47D cells. (B) $\mathrm{SKBr} 3$ cells. ${ }^{*} \mathrm{P}<0.05$, vs. $\mathrm{Cu} \mathrm{B} ;{ }^{* *} \mathrm{P}<0.01$, vs. $\mathrm{Cu} \mathrm{B}$;

${ }^{* * * *} \mathrm{P}<0.001$, vs. $\mathrm{Cu}$ B. Cu B, cucurbitacin B; C + H, Cu B + higenamine.

A Control
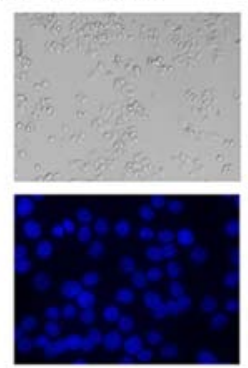

B Control
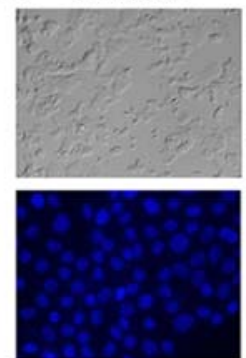

$\mathrm{Cu} \mathrm{B}$
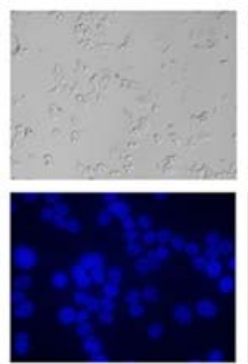

$\mathrm{Cu} \mathrm{B}$
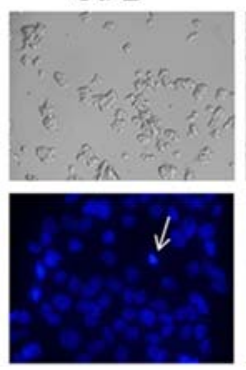

Higenamine
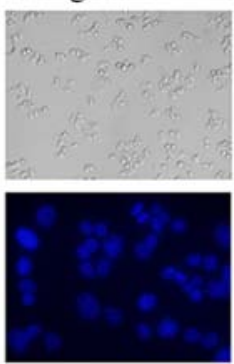

Higenamine
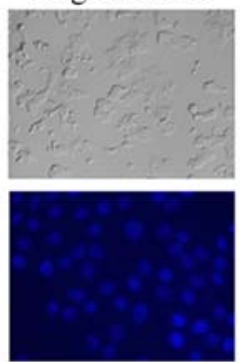

$\mathrm{C}+\mathrm{H}$
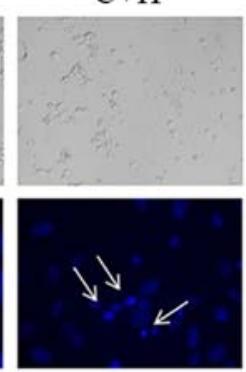

Cucurbitacin B (nM)

ㅁ Higenamine $(\mathrm{nM})$

- $\mathrm{C}+\mathrm{H}(10: 1)$ Cucurbitacin B $(\mu \mathrm{M})$ 다을 $\mathrm{C}(30: 1)$
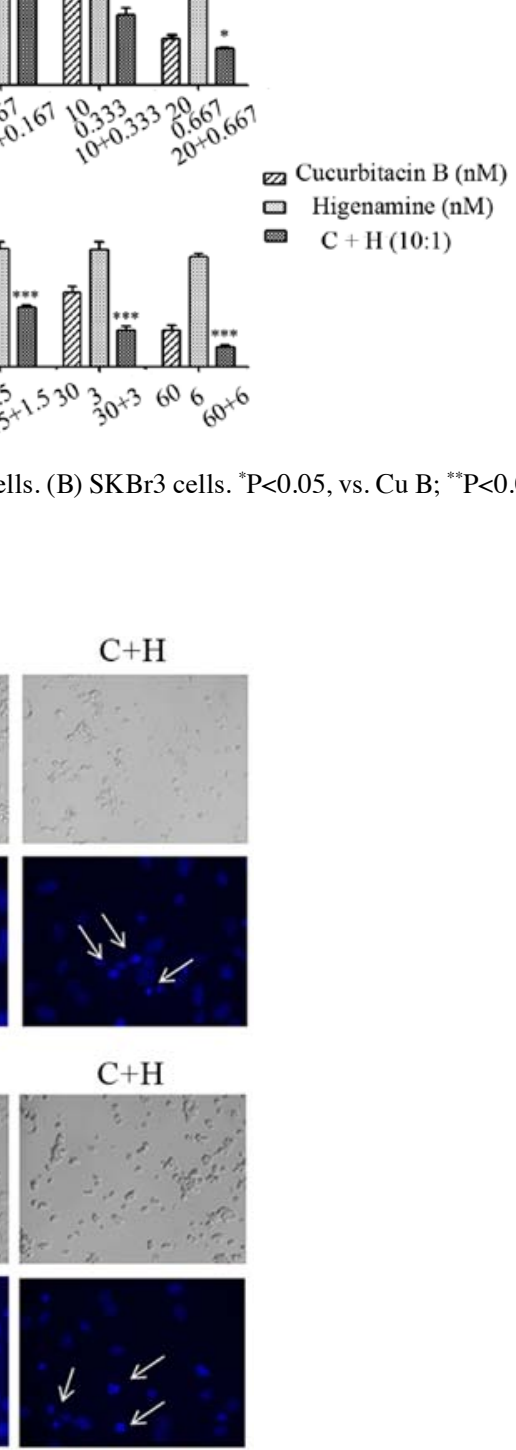

Figure 2. Effect of $\mathrm{Cu} \mathrm{B}$ combined with higenamine on changes of morphologic features (the upper row in both $\mathrm{A}$ and $\mathrm{B}, \mathrm{x} 100$ magnification) and DAPI staining (the lower row in both A and B, x400 magnification) in breast cancer cell lines. (A) SKBr3 cells; (B) T47D cells. Cu B, cucurbitacin B; C + H, $\mathrm{Cu} \mathrm{B}+$ higenamine. Arrows indicate the nuclear chromatin condensation and granular apoptotic bodies. 

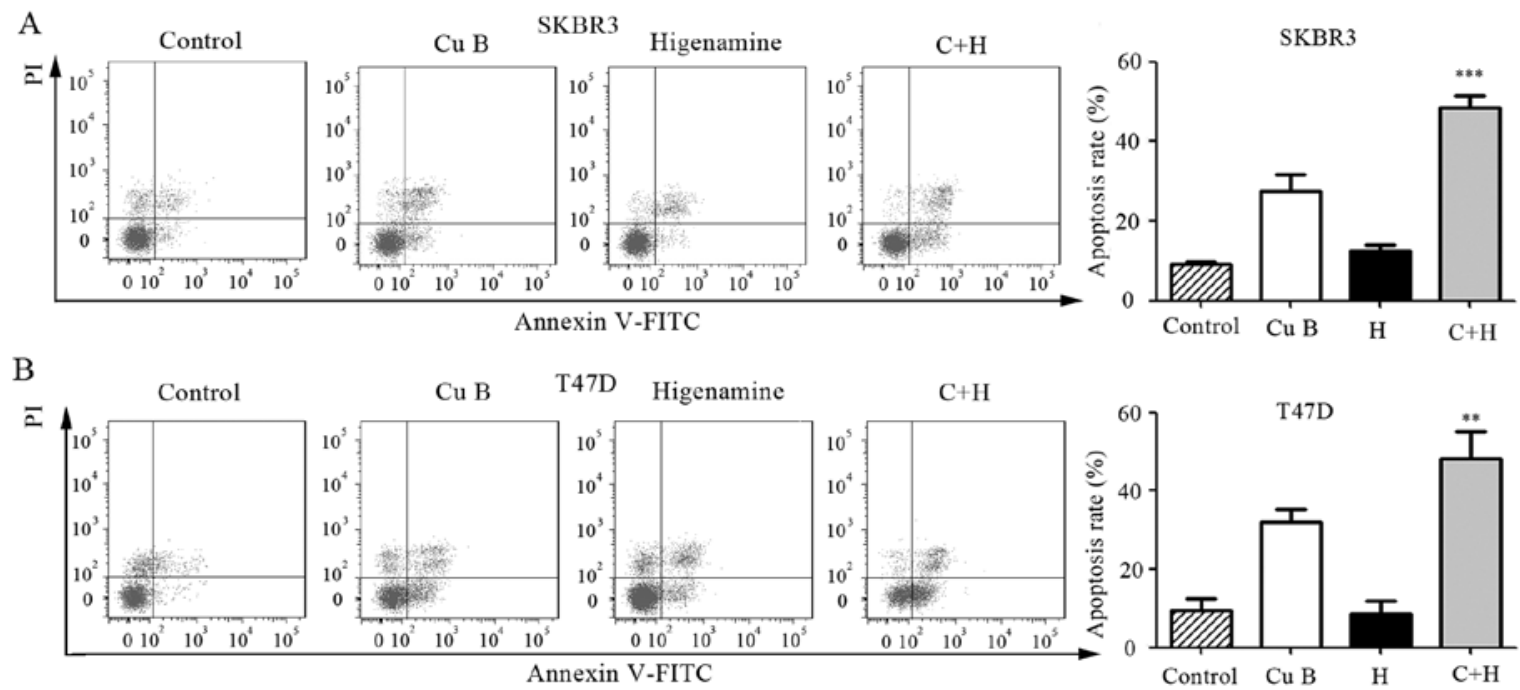

Figure 3. Effect of $\mathrm{Cu} B$ combined with higenamine on apoptosis. (A) SKBr3 cells. (B) T47D cells. ${ }^{* * *} \mathrm{P}<0.01$, vs. Cu B; ${ }^{* * * *} \mathrm{P}<0.001, \mathrm{vs}$. Cu B. Cu B, cucurbitacin $\mathrm{B} ; \mathrm{H}$, higenamine; $\mathrm{C}+\mathrm{H}, \mathrm{Cu} \mathrm{B}+$ higenamine.
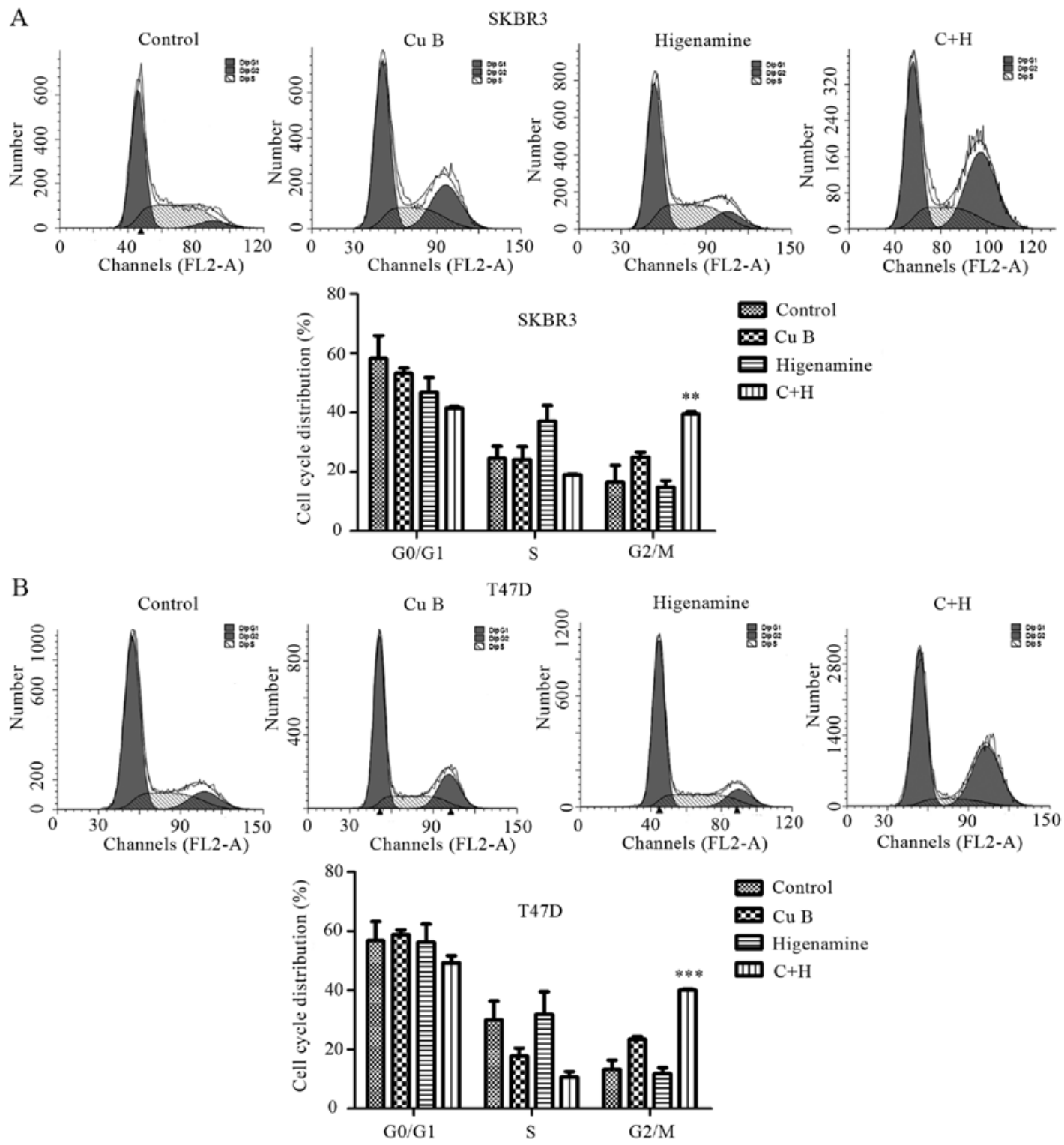

Figure 4. Effect of $\mathrm{Cu} B$ combined with higenamine on cell cycle. (A) SKBr3 cells. (B) T47D cells. ${ }^{* *} \mathrm{P}<0.01$, vs. Cu B; ${ }^{* * * *} \mathrm{P}<0.001$, vs. Cu B. Cu B, cucurbitacin $\mathrm{B} ; \mathrm{C}+\mathrm{H}, \mathrm{Cu} \mathrm{B}+$ higenamine. 


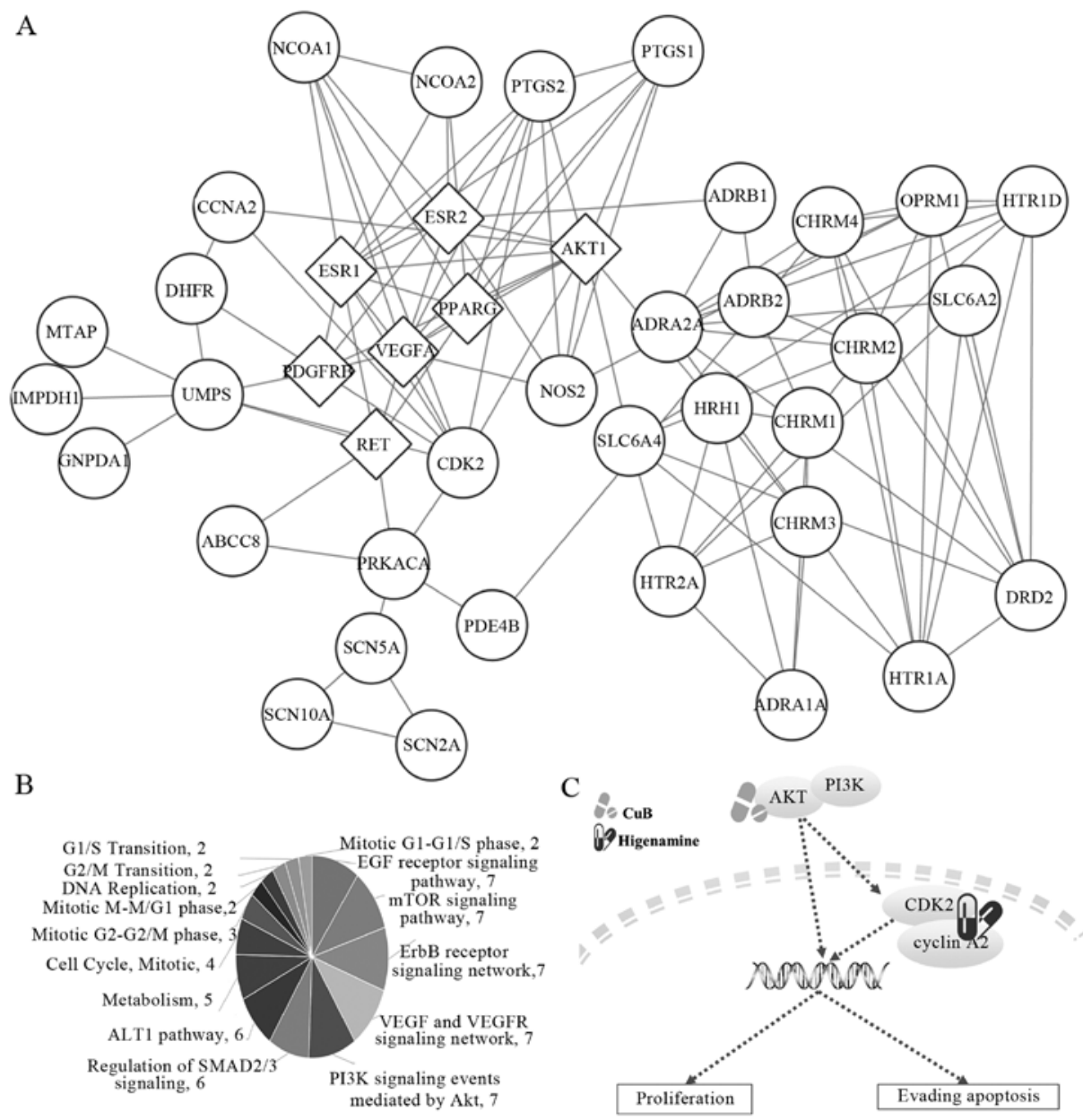

Figure 5. Predicted results of network pharmacology. (A) Protein-protein interactions of major targets of Cu B and the predicted targets of higenamine. Squares represent the major targets of $\mathrm{Cu}$ B; circles represent the predicted targets of higenamine. (B) Results of pathway analysis by FunRich. (C) Possible mechanism underlying the effects of the combination of $\mathrm{Cu} \mathrm{B}$ and higenamine in breast cancer treatment. $\mathrm{Cu} \mathrm{B}$, cucurbitacin $\mathrm{B}$.

cell cycle distribution following $\mathrm{Cu} \mathrm{B}$ and/or higenamine treatment using flow cytometry. $\mathrm{Cu} \mathrm{B}$ induced $\mathrm{G} 2 / \mathrm{M}$ phase arrest and the combination treatment resulted in a marked accumulation of cells in the G2/M phase compared with the treatment of $\mathrm{Cu}$ B alone in the SKBr3 (Fig. 4A) and T47D (Fig. 4B) cell lines.

Predicted mechanisms of $C u B$ and higenamine combination in breast cancer treatment. Using ChemMapper (data not shown), 119 predicted targets of $\mathrm{Cu} \mathrm{B}$ and 42 predicted targets of higenamine were obtained. The cell viability results showed that $\mathrm{Cu} \mathrm{B}$ exerted direct anti-breast cancer effects, suggesting that the predicted targets may be closely associated with the development of breast cancer. Therefore, these predicted targets were matched with the breast cancer treatment targets determined in our previous study. AKT1, estrogen receptor (ER), farnesyltransferase, CAAX box, $\alpha$ (FNTA), platelet-derived growth factor receptor $\alpha$ (PDGFRA), peroxisome proliferatoractivated receptor (PPAR), RET proto-oncogene (RET), and vascular endothelial growth factor A (VEGFA) were found to be directly associated with the anti-breast cancer effects. Therefore, AKT1, ER, FNTA, PDGFRA, PPAR, RET and VEGFA were considered to be the major targets of $\mathrm{Cu} B$ in breast cancer.

As the direct anti-breast cancer effects of higenamine remained to be elucidated, it was suggested that higenamine may enhance the curative effects of $\mathrm{Cu} B$ in breast cancer through target interactions. The protein interactions of the major targets of $\mathrm{Cu} \mathrm{B}$ and the whole predicted targets of higenamine were determined using the STRING database and the validated interactions were remapped through Cytoscape (Fig. 5A). Certain targets of higenamine interacted directly with the major targets of $\mathrm{Cu} \mathrm{B}$, including CCNA1, CDK2, dihydrofolate reductase (DHFR), uridine monophosphate synthetase (UMPS), ATP binding cassette subfamily C member 8 (ABCC8), protein kinase CAMP-activated catalytic subunit $\alpha$ (PRKACA), histamine receptor H1 (HRH1), solute carrier family 6 member 4 (SLC6A4), nitric oxide synthase 2 (NOS2), prostaglandin-endoperoxide synthase 2 (PTGS2), adrenoceptor $\beta 1$ (ADRB1), prostaglandin-endoperoxide synthase 1 (PTGS1), nuclear receptor coactivator (NCOA)1 and NCOA2. Pathway enrichment analysis was performed on these targets using the Comparative Toxicogenomics Database (Table I) and FunRich, respectively (Fig. 5B). Predominantly, these targets were enriched in metabolism-, cell cycle- and cancer-related signaling pathways. The metabolic functions of higenamine have been reported in cardiovascular disease treatment $(10,19-21)$. Therefore, the present study focused on the effects of higenamine on the cell cycle, particularly on targets CCNA2, CDK2 and PRKACA, according to the pathway analysis (Table I), which was accordance with our 
Table I. Pathways associated with the targets of higenamine, which has direct interactions with the major targets of $\mathrm{Cu} \mathrm{B}$.

\begin{tabular}{lll}
\hline Pathway & $\mathrm{n}$ & \multicolumn{1}{c}{ Annotated genes } \\
\hline Metabolism & 8 & ABCC8, DHFR, NCOA1, NCOA2, PRKACA, PTGS1, PTGS2, UMPS \\
Calcium signaling pathway & 4 & ADRB1, HRH1, NOS2, PRKACA \\
Cell Cycle, mitotic & 4 & CCNA2, CDK2, DHFR, PRKACA \\
G1/S transition & 3 & CCNA2, CDK2, DHFR \\
Mitotic G1-G1/S phases & 3 & CCNA2, CDK2, DHFR \\
G2/M transition & 3 & CCNA2, CDK2, PRKACA \\
Mitotic G2-G2/M phases & 3 & CCNA2, CDK2, PRKACA
\end{tabular}

$\mathrm{Cu}$ B, cucurbitacin B; ABCC8, ATP binding cassette subfamily C member 8; DHFR, dihydrofolate reductase; NCOA, nuclear receptor coactivator; PRKACA, protein kinase CAMP-activated catalytic subunit $\alpha$; PTGS, prostaglandin-endoperoxide synthase; UMPS, uridine monophosphate synthetase; ADRB1, adrenoceptor $\beta 1$; HRH1, histamine receptor H1; NOS2, nitric oxide synthase 2; CCNA2, cyclin A2; CDK2, cyclin-dependent kinase 2.

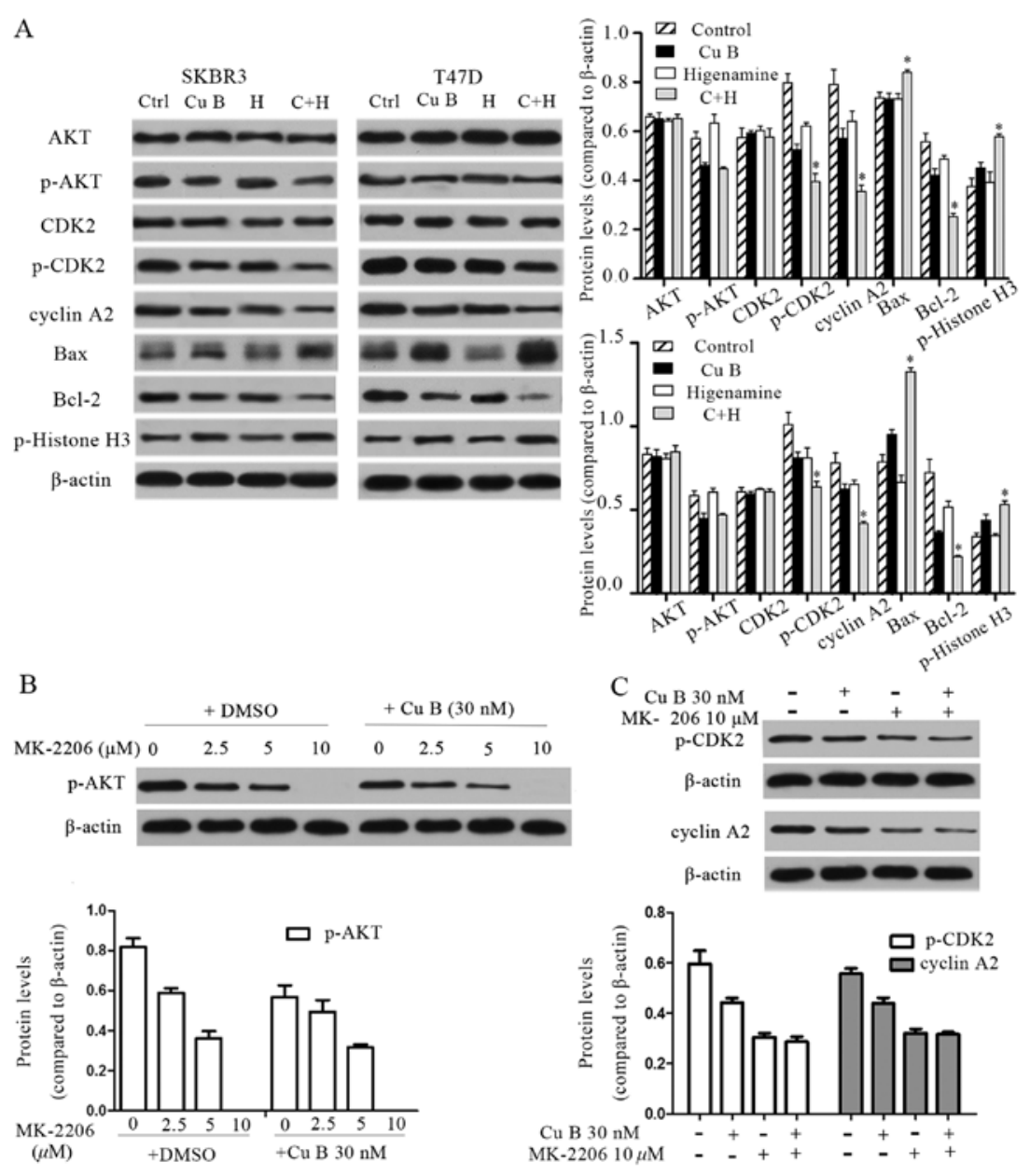

Figure 6. Verification of predicted molecular mechanism. (A) Effect of $\mathrm{Cu} \mathrm{B}$, higenamine and combination treatment on protein expression in breast cancer cells. "P $\mathrm{P}<.05$, vs. $\mathrm{Cu}$ B. (B) Effect of MK-2206 and $\mathrm{Cu}$ B on the protein expression of p-AKT in SKBr3 cells. (C) Effect of Cu B on the expression of p-CDK2 and cyclin A2 in SKBr3 cells when p-AKT was inhibited. $\mathrm{Cu}$ B, cucurbitacin B; C + H, Cu B + higenamine (10:1); CDK2, cyclin-dependent kinase 2; Bcl-2, B-cell lymphoma 2; Bax, Bcl-2-associated X protein; p-, phosphorylated; DMSO, dimethylsulfoxide.

experiment results. PRKACA can interact with RET, the target of $\mathrm{Cu} \mathrm{B}$. However, AKT was the downstream effector target of ER, VEGFR and RET, which were all targets of $\mathrm{Cu} B$, and can directly interact with CDK2 and CCNA2. Therefore, the present study focused on AKT, CDK2 and CCNA2. The associated pathways were summarized by KEGG pathway analysis (Fig. 5C) and it was found that AKT may be the key target of $\mathrm{Cu} \mathrm{B}$, and $\mathrm{CDK} 2$ and CCNA 2 may be the key targets of higenamine, respectively.

Western blot analysis of predicted key targets. To clarify the anti-breast cancer mechanism of $\mathrm{Cu} \mathrm{B}$ and the mechanism 


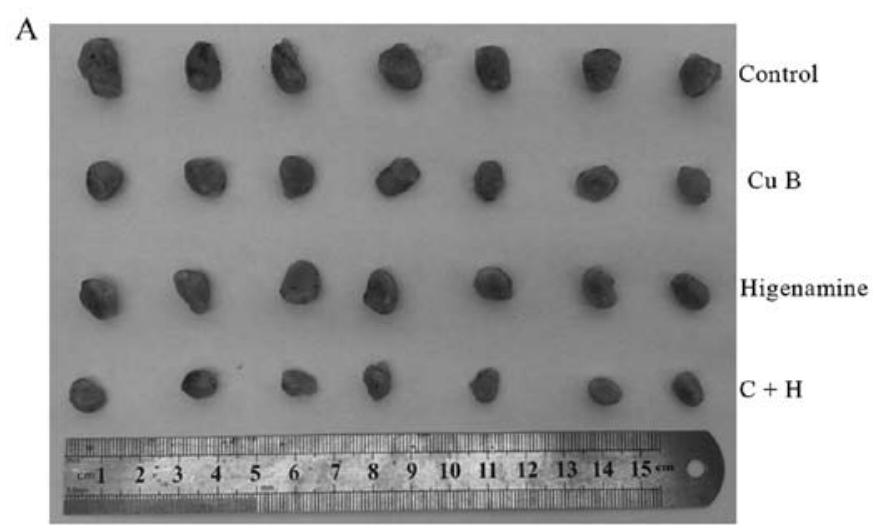

B

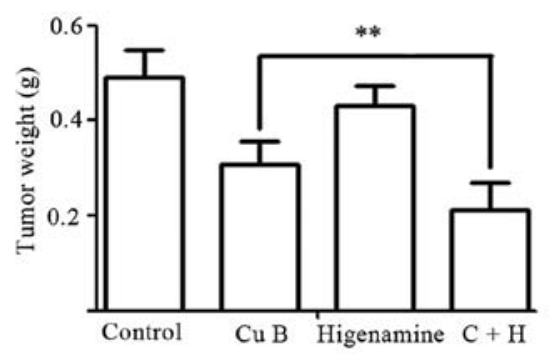

C
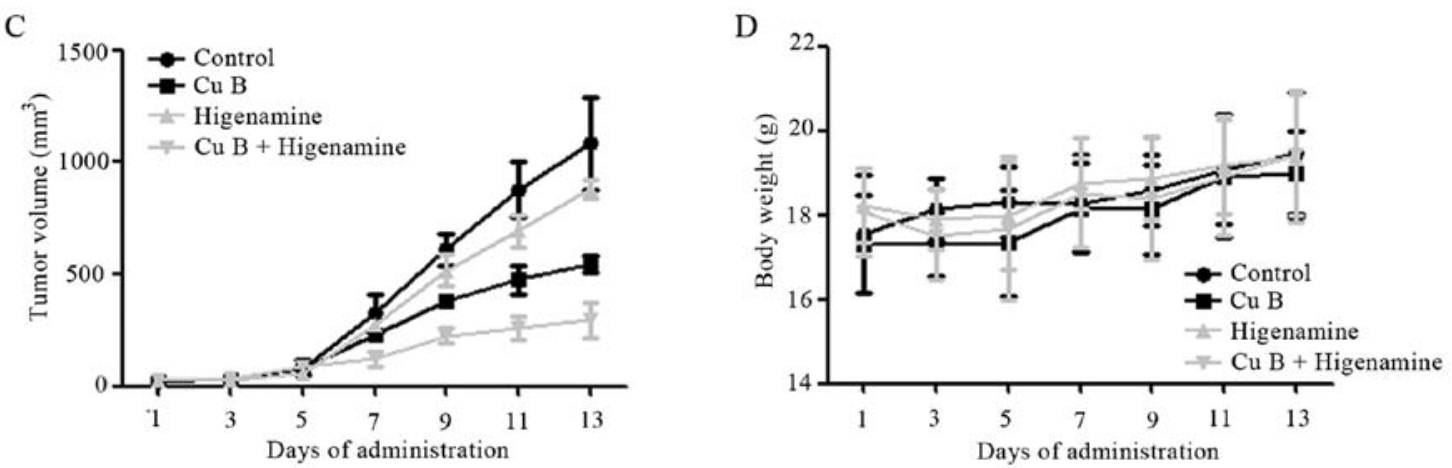

Figure 7. Higenamine augments the in vivo therapeutic effects of $\mathrm{Cu} \mathrm{B}$ and higenamine on SKBr3-transplanted tumors. (A) Representative image of excised tumors. Effects of $\mathrm{Cu} \mathrm{B}$, higenamine, or combination treatment on $(\mathrm{B})$ tumor weight, $(\mathrm{C})$ tumor volume and (D) body weight. ${ }^{* *} \mathrm{P}<0.01$. $\mathrm{Cu} \mathrm{B}$, cucurbitacin $\mathrm{B}$; $\mathrm{C}+\mathrm{H}, \mathrm{Cu} \mathrm{B}+$ higenamine (10:1).

through which higenamine enhanced the antitumor activities of $\mathrm{Cu} \mathrm{B}$, the activity of AKT and CDK2 and the expression of CCNA2 were evaluated using western blot analysis. As shown in Fig. 6A, the levels of total AKT and CDK2 were not altered, however, the phosphorylation of AKT at Serine 473 and of CDK2 at Threonine 39 were reduced following $\mathrm{Cu} B$ treatment. Only marginal reductions in the activity of CDK2 and the expression of CCNA2 were observed following treatment with higenamine. The activity of CDK2 and the expression of CCNA2 were significantly reduced following the combination treatment. The expression of p-histone H3 was increased following the combination treatment compared with the level following treatment with $\mathrm{Cu} \mathrm{B}$ (Fig. 6A), which was indicative of the enhanced G2/M arrest described above. Treatment with the AKT inhibitor, MK-2206, alone and together with $\mathrm{Cu} \mathrm{B}$ further supported the conclusion that $\mathrm{Cu} \mathrm{B}$ can downregulate the phosphorylation of AKT. Treatment with $10 \mu \mathrm{M}$ of MK-2206 inhibited the phosphorylation of AKT (Fig. 6B). Furthermore, $10 \mu \mathrm{M}$ of MK-2206 reduced the phosphorylation of CDK2 and the expression of CCNA2, which supported the close associations of AKT, CDK2 and CCNA2. Compared with $10 \mu \mathrm{M}$ of MK-2206, p-CDK2 and CCNA2 were not affected by $30 \mathrm{nM}$ of $\mathrm{Cu}$ B combined with $10 \mu \mathrm{M}$ of MK-2206, which also suggested that CDK2 and CCNA2 were the downstream effectors of AKT (Fig. 6C). These results suggested that $\mathrm{Cu} \mathrm{B}$ exerted anti-breast cancer effects through inhibiting the activity of the AKT pathway, and that the synergetic inhibition induced by the combination of $\mathrm{Cu} \mathrm{B}$ and higenamine was most likely a result of cell cycle-related pathways triggered by CDK2 and CCNA2.
Effects of $C u B$ and higenamine in vivo. To further evaluate the antitumor efficacy of $\mathrm{Cu} \mathrm{B}$ and higenamine in vivo, $\mathrm{BALB} / \mathrm{c}$ nude mice with $\mathrm{SKBr} 3$ xenografts were treated with $\mathrm{Cu} \mathrm{B}$ and/or higenamine. The surviving implanted mice were randomly divided into four groups. There were no statistical differences among the sizes of the groups (all $\mathrm{P}>0.05$ ). Representative images of the excised tumors are shown in Fig. 7A. After 13 days, the combination treatment markedly and effectively suppressed tumor growth, with a reduction in the tumor weights of 31.45 and $51.07 \%$ compared with those in the single treatment groups with $\mathrm{Cu} B(\mathrm{P}<0.01)$ and higenamine $(\mathrm{P}<0.001)$, respectively (Fig. 7B and $\mathrm{C})$. Compared with the control, no significant difference in body weight gain was observed following treatment with $\mathrm{Cu} \mathrm{B}$, higenamine, or the two in combination (Fig. 7D). In addition, no differences were observed in the organ indices for the heart, liver, spleen, lung or kidney between the control and other groups (all $\mathrm{P}>0.05$; data not shown).

\section{Discussion}

T.kirilowii Maxim. has been used for approximate nine hundred years in TCM and its antitumor effects have been the subject of previous studies $(25,26)$. In the present study, a component of this herb, $\mathrm{Cu} \mathrm{B}$, was combined with higenamine to determine whether the antitumor effect of $\mathrm{Cu} B$ was enhanced in breast cancer cells. Aconitine, which is a component in Radix Aconiti Lateralis Preparata, was also assessed, but resulted in an unsatisfactory result (data not shown). The data obtained suggested that higenamine enhanced the inhibitory effect of 
$\mathrm{Cu} \mathrm{B}$ on breast cancer, as demonstrated through the analysis of growth inhibition, cell cycle arrest, and apoptosis. $\mathrm{Cu} \mathrm{B}$ inhibited breast cancer in a dose- and time-dependent manner. However, a 10:1 (Cu B:higenamine) ratio was optimal for the combination treatment of breast cancer. In accordance with compatibility of herb-partners in TCM, different proportions are used to treat different diseases.

Network pharmacology methods were used to predict the possible mechanism through which higenamine potentiated the treatment effect of $\mathrm{Cu}$ B. It was found that AKT1, ER, FNTA, PDGFRA, PPAR, RET and VEGFA were the major targets of $\mathrm{Cu} \mathrm{B}$ in breast cancer. As the direct anti-breast cancer effects of higenamine were unclear, the protein-protein interactions with the major targets of $\mathrm{Cu} \mathrm{B}$ and all the predicted targets of higenamine were analyzed to identify the possible targets through which the synergistic action of higenamine was mediated. CCNA1, CDK2, DHFR, UMPS, ABCC8, PRKACA, HRH1, SLC6A4, NOS2, PTGS2, ADRB1, PTGS1, NCOA1 and NCOA2 were found to have direct interactions with the major targets of $\mathrm{Cu} \mathrm{B}$. These targets were mainly enriched in metabolism and cell cycle. The metabolic functions of higenamine are well established in cardiovascular disease treatment $(13,22-24)$. Therefore, the present study focused on the effects of higenamine on the cell cycle, particularly on the targets of CCNA2, CDK2, DHFR and PRKACA. To better understand the predicted mechanism of $\mathrm{Cu} \mathrm{B}$ combined with higenamine in breast cancer treatment, the associated pathways were summarized by KEGG pathway analysis (Fig. 5C) and it was found that AKT may be the key target of $\mathrm{Cu} \mathrm{B}$, and CDK2 and CCNA2 may be the key targets of higenamine, respectively. This was supported by the cell cycle results, which showed that higenamine increased the accumulation of G2/M arrest compared with $\mathrm{Cu} \mathrm{B}$ treatment alone. The potentiated apoptotic effect may result from inhibition of the activity of CDK2 (27). Apoptosis was verified by the increased expression of Bax and the decreased expression of Bcl-2. Several studies have reported that inhibiting the activity of AKT and CDK2 suppresses breast cancer cell growth (28-31); the results of the cell viability assay in the present study correlated with this.

The activity of AKT and CDK2, and the expression of CCNA2, were further evaluated by western blot analysis. The inhibitory effect of $\mathrm{Cu} \mathrm{B}$ treatment was clear. Higenamine treatment alone exerted a modest effect on the activity of CDK2 and the expression of CCNA2, whereas the combination treatment resulted in marked inhibition of the activity of CDK2 and expression of CCNA2. This suggested that the anti-breast cancer effects of $\mathrm{Cu} \mathrm{B}$ were mediated through the inhibition of AKT pathway activity, and that the enhanced inhibitory effect induced by $\mathrm{Cu} \mathrm{B}$ and higenamine combination treatment was likely to be a result of cell cycle-related pathways triggered by CDK2 and CCNA2.

Despite the above findings, the cell cycle arrest and cell viability inhibition induced by higenamine only had a modest effect on the activity of CDK2 and the expression of CCNA2. It was reported previously that human colon cancer cell lines proliferated normally following the depletion of CDK2 $(32,33)$ and the viability of CDK2-knockout mice was confirmed (34), which indicated that CDK2 was not required for cell cycle progression in immortalized human cell lines; therefore, the inhibition of CDK2 only does not offer a promising strategy for cancer therapy. AKT regulates cell cycle progression in the G1/S and $\mathrm{G} 2 / \mathrm{M}$ phases through either the direct phosphorylation of or the indirect regulation of the expression of various substrates, including, but not limited to, CDK2, p21waf1, p27kip1, c-Myc, glycogen synthase kinase 3 $\beta, \mathrm{CCND} 1$ and forkhead box O3 (35). The AKT-mediated phosphorylation of CDK2 and the altered subcellular localizations are important for cell cycle progression from the $\mathrm{S}$ to the $\mathrm{G} 2 / \mathrm{M}$ phase (27). Therefore, the combination of higenamine and $\mathrm{Cu} \mathrm{B}$ resulted in the marked inhibition of CDK2 activity and arrest of the cell cycle.

Due to the limited funding, the present study did not examine the effects of $\mathrm{Cu} \mathrm{B}$ on normal cells. Therefore, associated experiments are required in the future.

In conclusion, the present study demonstrated that growth inhibition by the combination of $\mathrm{Cu} \mathrm{B}$ and higenamine in breast cancer cells resulted from cell cycle arrest and the induction of apoptosis. $\mathrm{Cu}$ B exerted anti-breast cancer effects through inhibition of the activity of the AKT pathway, and the synergistic inhibition induced by the combination treatment of $\mathrm{Cu} \mathrm{B}$ and higenamine was likely a result of CDK2 and CCNA2.

\section{Acknowledgements}

Not applicable.

\section{Funding}

The present study was supported by the National Natural Science Foundation of China (grant nos. 81503383 and 81400321).

\section{Availability of data and materials}

The datasets used during the present study are available from the corresponding author upon reasonable request.

\section{Authors' contributions}

XZW and DC conceived and designed the study. ZQJ, JH, XY, JL, JWY, YM, DL and RC performed the experiments. ZQJ and $\mathrm{JH}$ wrote the manuscript. DC, JHH and XL contributed to the analysis and interpretation of data. All authors read and approved the manuscript and agree to be accountable for all aspects of the research in ensuring that the accuracy or integrity of any part of the work are appropriately investigated and resolved.

\section{Ethics approval and consent to participate}

The present study was approved by the Committee on the Ethics of Animal Experiments of Tianjin Medical University Cancer Institute and Hospital (permit no. 2017083).

\section{Patient consent for publication}

Not applicable.

\section{Competing interests}

The authors declare that they have no competing interests. 


\section{References}

1. Siegel RL, Miller KD and Jemal A: Cancer statistics, 2018. CA Cancer J Clin 68: 7-30, 2018.

2. Sun Y, Zhang J, Zhou J, Huang Z, Hu H, Qiao M, Zhao X and Chen D: Synergistic effect of cucurbitacin B in combination with curcumin via enhancing apoptosis induction and reversing multidrug resistance in human hepatoma cells. Eur J Pharmacol 768: 28-40, 2015.

3. Ding X, Chi J, Yang X, Hao J, Liu C, Zhu C, Wang X, Liu X, Niu Y, Ji W, et al: Cucurbitacin B synergistically enhances the apoptosis-inducing effect of arsenic trioxide by inhibiting STAT3 phosphorylation in lymphoma Ramos cells. Leuk Lymphoma 58: 2439-2451, 2017.

4. Sun SM: Qian Jin Yi Fang Jiao Shi. Li JR, Su L, Ren JL, Jiao ZL and Li PZ (eds). People's Medical Publishing House, Beijing, p324, 1998.

5. Zhao JC: Sheng Ji Zong Lu Zhuan Yao. Yu YA, Wang LX, Li JR and Wu JH (eds.) Anhui: Science \& Technology Publishing House: Anhui, pp. 63-64, 1987.

6. Zhang ZJ: Jin Gui Yao Lue. Fan YS (ed). Chinese Press of Traditional Chinese Medicine, Beijing, p223, 2003.

7. Kausar H, Munagala R, Bansal SS, Aqil F, Vadhanam MV and Gupta RC: Cucurbitacin B potently suppresses non-small-cell lung cancer growth: Identification of intracellular thiols as critical targets. Cancer Lett 332: 35-45, 2013.

8. Zhou X, Yang J, Wang Y, Li W, Li-Ling J, Deng Y and Zhang M: Cucurbitacin B inhibits 12-O-tetradecanoylphorbol 13-acetate-induced invasion and migration of human hepatoma cells through inactivating mitogen-activated protein kinase and $\mathrm{PI} 3 K / A k t$ signal transduction pathways. Hepatol Res 42: 401-411, 2012.

9. Yar Saglam AS, Alp E, Elmazoglu Z and Menevse S: Treatment with cucurbitacin B alone and in combination with gefitinib induces cell cycle inhibition and apoptosis via EGFR and JAK/STAT pathway in human colorectal cancer cell lines. Hum Exp Toxicol 35: 526-543, 2016.

10. Zhang M, Sun C, Shan X, Yang X, Li-Ling J and Deng Y: Inhibition of pancreatic cancer cell growth by cucurbitacin $B$ through modulation of signal transducer and activator of transcription 3 signaling. Pancreas 39: 923-929, 2010.

11. Zhang N, Lian Z, Peng X, Li Z and Zhu H: Applications of Higenamine in pharmacology and medicine. J Ethnopharmacol 196: 242-252, 2017.

12. Bai G, Yang Y, Shi Q, Liu Z, Zhang Q and Zhu YY: Identification of higenamine in Radix Aconiti Lateralis Preparata as a beta2-adrenergic receptor agonist1. Acta Pharmacol Sin 29: 1187-1194, 2008.

13. Lee SR, Schriefer JM, Gunnels TA, Harvey IC and Bloomer RJ: Acute oral intake of a higenamine-based dietary supplement increases circulating free fatty acids and energy expenditure in human subjects. Lipids Health Dis 12: 148, 2013.

14. Yuan H, Ma Q, Cui H, Liu G, Zhao X, Li W, Piao G: How can synergism of traditional medicines benefit from network pharmacology? Molecules 22: 1135, 2017.

15. Gong J, Cai C, Liu X, Ku X, Jiang H, Gao D and Li H: ChemMapper: A versatile web server for exploring pharmacology and chemical structure association based on molecular 3D similarity method. Bioinformatics 29: 1827-1829, 2013.

16. Bolton EE, Wang Y, Thiessen PA and Bryant SH: PubChem: Integrated platform of small molecules and biological activities. Annu Rep Comput Chem 4: 217-241, 2008.

17. Mao Y, Hao J, Jin ZQ, Niu YY, Yang X, Liu D, Cao R and Wu XZ: Network pharmacology-based and clinically relevant prediction of the active ingredients and potential targets of Chinese herbs in metastatic breast cancer patients. Oncotarget 8: 27007-27021, 2017.

18. von Mering C, Jensen LJ, Snel B, Hooper SD, Krupp M, Foglierini M, Jouffre N, Huynen MA and Bork P: STRING: Known and predicted protein-protein associations, integrated and transferred across organisms. Nucleic Acids Res 33: D433-D437, 2005.
19. Shannon P, Markiel A, Ozier O, Baliga NS, Wang JT, Ramage D, Amin N, Schwikowski B and Ideker T: Cytoscape: A software environment for integrated models of biomolecular interaction networks. Genome Res 13: 2498-2504, 2003.

20. Davis AP, Grondin CJ, Lennon-Hopkins K, Saraceni-Richards C, Sciaky D, King BL, Wiegers TC and Mattingly CJ: The comparative toxicogenomics database's 10th year anniversary: Update 2015. Nucleic Acids Res 43 (D1): D914-D920, 2015.

21. Pathan M, Keerthikumar S, Ang CS, Gangoda L, Quek CY, Williamson NA, Mouradov D, Sieber OM, Simpson RJ, Salim A, et al: FunRich: An open access standalone functional enrichment and interaction network analysis tool. Proteomics 15: 2597-2601, 2015.

22. Liu XJ, Wagner HN Jr and Tao S: Measurement of effects of the Chinese herbal medicine higenamine on left ventricular function using a cardiac probe. Eur J Nucl Med 8: 233-236, 1983.

23. Feng S, Jiang J, Hu P, Zhang JY, Liu T, Zhao Q and Li BL: A phase I study on pharmacokinetics and pharmacodynamics of higenamine in healthy Chinese subjects. Acta Pharmacol Sin 33: 1353-1358, 2012

24. Kang YJ, Lee YS, Lee GW, Lee DH, Ryu JC, Yun-Choi HS and Chang KC: Inhibition of activation of nuclear factor kappaB is responsible for inhibition of inducible nitric oxide synthase expression by higenamine, an active component of aconite root. J Pharmacol Exp Ther 291: 314-320, 1999.

25. Ni L, Zhu X, Gong C, Luo Y, Wang L, Zhou W, Zhu S and Li Y: Trichosanthes kirilowii fruits inhibit non-small cell lung cancer cell growth through mitotic cell-cycle arrest. Am J Chin Med 43: 349-364, 2015.

26. Oh H, Mun YJ, Im SJ, Lee SY, Song HJ, Lee HS and Woo WH: Cucurbitacins from Trichosanthes kirilowii as the inhibitory components on tyrosinase activity and melanin synthesis of B16/F10 melanoma cells. Planta Med 68: 832-833, 2002.

27. Maddika S, Ande SR, Wiechec E, Hansen LL, Wesselborg S and Los M: Akt-mediated phosphorylation of CDK2 regulates its dual role in cell cycle progression and apoptosis. J Cell Sci 121: 979-988, 2008.

28. Sliva D, Jedinak A, Kawasaki J, Harvey K and Slivova V: Phellinus linteus suppresses growth, angiogenesis and invasive behaviour of breast cancer cells through the inhibition of AKT signalling. Br J Cancer 98: 1348-1356, 2008.

29. Zakikhani M, Blouin MJ, Piura E and Pollak MN: Metformin and rapamycin have distinct effects on the AKT pathway and proliferation in breast cancer cells. Breast Cancer Res Treat 123: 271-279, 2010.

30. Caffarel MM, Andradas C, Mira E, Pérez-Gómez E, Cerutti C, Moreno-Bueno G, Flores JM, García-Real I, Palacios J, Mañes S, et al: Cannabinoids reduce ErbB2-driven breast cancer progression through Akt inhibition. Mol Cancer 9: 196, 2010.

31. Teixeira $C$ and Pratt MA: CDK2 is a target for retinoic acidmediated growth inhibition in MCF-7 human breast cancer cells. Mol Endocrinol 11: 1191-1202, 1997.

32. Tetsu O and McCormick F: Proliferation of cancer cells despite CDK2 inhibition. Cancer Cell 3: 233-245, 2003.

33. Ortega S, Prieto I, Odajima J, Martín A, Dubus P, Sotillo R, Barbero JL, Malumbres M and Barbacid M: Cyclin-dependent kinase 2 is essential for meiosis but not for mitotic cell division in mice. Nat Genet 35: 25-31, 2003.

34. Berthet C, Aleem E, Coppola V, Tessarollo L and Kaldis P: Cdk2 knockout mice are viable. Curr Biol 13: 1775-1785, 2003.

35. Liang J and Slingerland JM: Multiple roles of the PI3K/PKB (Akt) pathway in cell cycle progression. Cell Cycle 2: 339-345, 2003. 